Article

\title{
Comparative Transcriptome Analysis of Two Contrasting Soybean Varieties in Response to Aluminum Toxicity
}

\author{
Lijuan Zhao ${ }^{1}$, Jingjing Cui ${ }^{1}$, Yuanyuan Cai ${ }^{1}$, Songnan Yang ${ }^{1}{ }^{(}$, , Juge Liu ${ }^{1}$, Wei Wang ${ }^{1}$, \\ Junyi Gai ${ }^{1}$, Zhubing $\mathrm{Hu}^{2}$ and $\mathrm{Yan} \mathrm{Li}^{1, *}{ }^{1}$ \\ 1 National Key Laboratory of Crop Genetics and Germplasm Enhancement, National Center for Soybean \\ Improvement, Key Laboratory for Biology and Genetic Improvement of Soybean (General, Ministry of \\ Agriculture), Jiangsu Collaborative Innovation Center for Modern Crop Production, Nanjing Agricultural \\ University, Nanjing 210095, China; zlj1525@126.com (L.Z.); jingjingcui@genovo.org (J.C.); \\ c1205048398@163.com (Y.C.); ysn785620774@126.com (S.Y.); luoyeyanhua@126.com (J.L.); \\ Weiwang1012@126.com (W.W.); sri@njau.edu.cn (J.G.) \\ 2 College of Life Sciences, Nanjing Agricultural University, Nanjing 210095, China; huzhubing@njau.edu.cn \\ * Correspondence: yanli1@njau.edu.cn
}

Received: 1 May 2020; Accepted: 12 June 2020; Published: 17 June 2020

\begin{abstract}
Aluminum (Al) toxicity is a major factor limiting crop productivity on acid soils. Soybean (Glycine max) is an important oil crop and there is great variation in Al tolerance in soybean germplasms. However, only a few Al-tolerance genes have been reported in soybean. Therefore, the purpose of this study was to identify candidate $\mathrm{Al}$ tolerance genes by comparative transcriptome analysis of two contrasting soybean varieties in response to Al stress. Two soybean varieties, M90-24 (M) and Pella (P), which showed significant difference in Al tolerance, were used for RNA-seq analysis. We identified a total of 354 Al-tolerance related genes, which showed up-regulated expression by $\mathrm{Al}$ in the Al-tolerant soybean variety $\mathrm{M}$ and higher transcript levels in $\mathrm{M}$ than $\mathrm{P}$ under $\mathrm{Al}$ stress. These genes were enriched in the Gene Ontology (GO) terms of cellular glucan metabolic process and regulation of transcription. Five out of 11 genes in the enriched GO term of cellular glucan metabolic process encode cellulose synthases, and one cellulose synthase gene (Glyma.02G205800) was identified as the key hub gene by co-expression network analysis. Furthermore, treatment of soybean roots with a cellulose biosynthesis inhibitor decreased the $\mathrm{Al}$ tolerance, indicating an important role of cellulose production in soybean tolerance to $\mathrm{Al}$ toxicity. This study provides a list of candidate genes for further investigation on $\mathrm{Al}$ tolerance mechanisms in soybean.
\end{abstract}

Keywords: aluminum; cellulose; gene ontology (GO) enrichment; RNA-seq; soybean

\section{Introduction}

Acid soils comprise up to $50 \%$ of the potentially arable land in the world [1,2] and about $21 \%$ of total arable land in China [3]. In acid soils, aluminum (Al) toxicity has a detrimental effect on crop productivity [4,5], which can cause $30 \%$ to $40 \%$ of yield loss in rice and other cereals [6]. Al toxicity can damage and restrain the growth of plant roots, and affect the absorption of nutrients and water, leading to the reduction in crop yield $[2,7,8]$. Al limits the growth of roots by inhibition of cell division, cell elongation or both [8-10], and the undeveloped roots under Al toxicity might be due to the structural and functional damage to roots [11,12].

Studies have suggested that the cell wall is the first barrier when plant roots interact with $\mathrm{Al}$ in acid soil, and also the major pool of $\mathrm{Al}$ in plants. Al-induced inhibition of cell elongation in the hypocotyl of Abelmoschus esculentus was mainly due to the Al-binding in epidermis, and $95 \%$ of the $\mathrm{Al}$ in epidermis 
was in the cell wall [13]. Another study found that about $85 \%$ of the $\mathrm{Al}$ was accumulated in the cell wall of roots in Zea mays [14]. Many studies also showed that the main Al-binding sites in cell wall are polysaccharides [15-17]. The contents of cell wall polysaccharides, including pectin, hemi-cellulose, and cellulose, were increased by $\mathrm{Al}$ in the roots of Cucurbita maxima Duch. [18]. In addition to the direct Al-binding, the plant cell wall is also associated with ectopic lignin deposition, and activation of jasmonate and ethylene signalling pathways $[19,20]$.

Plants have developed several strategies against Al toxicity, which are categorized into two main mechanisms, including internal tolerance and external detoxification [2,12]. With internal tolerance, plants tolerate $\mathrm{Al}$ toxicity either through binding $\mathrm{Al}$ to pectin and hemi-cellulose in the root cell wall $[17,21]$ or forming $\mathrm{Al}$ chelation that occurs inside the cell and then compartmentalized in other organelles like vacuole. For example, in buckwheat (Fagopyrum esculentum Moench), internal detoxification of $\mathrm{Al}$ is achieved by $\mathrm{Al}$-oxalate and this complex was sequestrated in the vacuoles of the leaves [22-25]. Two genes from buckwheat, FeALS1.1 and FeALS1.2, which belong to the half-size $\mathrm{ABC}$ transporter genes, were found to play a role in the internal detoxification of $\mathrm{Al}$ [26]. For external detoxification, plant root apexes exudate organic acids to chelate $\mathrm{Al}$ in the rhizosphere [27-29]. The first malate transporter gene, TaALMT1 (encoding an aluminum-activated malate transporter, ALMT), was isolated from the root tips of Al-tolerant wheat (Triticum aestivum L.) ET8 [30]. The malate transporter genes from other crops, such as BnALMT1 and BnALMT2 in rape (Brassica napus), GmALMT1 in soybean (G. max), and ScALMT1 in rye (Secale cereale L.), shared similar functional characteristics with TaALMT1 [31-34]. Multidrug and toxic compound extrusion (MATE) proteins facilitate citrate efflux from plant root apices, which can chelate and detoxify $\mathrm{Al}^{3+}$ in the apoplast and rhizosphere around root apices [35]. The SbMATE1 gene was identified to confer Al tolerance in sorghum (Sorghum bicolor), which is the second cloned Al-tolerance gene in plants [35]. Subsequently, MATE genes were also found in other crops, for example, AtMATE in Arabidopsis, OsFRDL4 in rice, and ZmMATE1 in maize [28,36,37].

Soybean (Glycine max (L.) Merr.) is one of the most important legume crops in the world, which provides oil and proteins for human food and feed [38]. Soybean is a moderately Al-tolerant crop [39], and there is a great variation in Al tolerance among different soybean varieties. Previous genetic [40] and physiological [41] studies showed that $\mathrm{Al}$ tolerance in soybean is a complex trait. However, there is limited information on $\mathrm{Al}$ tolerance genes in soybean. In addition to the known $\mathrm{Al}$ tolerance genes encoding ABC transporter, ALMT, and MATE [26,28,30,36,37], more genes related to Al tolerance need to be explored. In soybean, research on mapping the quantitative trait loci (QTL) underlying $\mathrm{Al}$ tolerance and identifying the Al-responsive genes by microarray analysis or cDNA-RAPD has been reported [42-44]. To our knowledge, there have been no reports on comparative transcriptomic analysis of soybean response to Al toxicity, which have been performed in other crops [45,46]. Combination of comparative analysis of gene expression profiles and phenotypic difference between Al-tolerant and sensitive soybean varieties could help us to identify candidate genes for Al tolerance. Therefore, in this study, we performed a comparative transcriptome analysis of two contrasting soybean varieties, M90-24 (Al-tolerant, M) and Pella (Al-sensitive, P), under Al stress and control condition, to identify candidate $\mathrm{Al}$ tolerance genes and the possible molecular basis of $\mathrm{Al}$ tolerance in soybean.

\section{Results}

\subsection{Relative Root Growth of Two Soybean Varieties under Al Stress}

Two soybean varieties, M90-24 (M) and Pella (P), were chosen for this study due to their difference in $\mathrm{Al}$ tolerance, as shown by their relative root growth (RRG) under $\mathrm{Al}$ stress compared with control conditions. The RRG of M was significantly greater than P after 6, 12 and $24 \mathrm{~h}$ of $25 \mu \mathrm{M} \mathrm{AlCl} \mathrm{Al}_{3}$ stress (Figure 1). The root growth of $\mathrm{P}$ was severely inhibited (RRG $=0.30$ ) after $24 \mathrm{~h}$ of $\mathrm{Al}$ stress, and therefore we chose 6 and $12 \mathrm{~h}$ as the time points to perform the comparative transcriptome analysis using the roots of these two soybean varieties under $\mathrm{Al}$ stress and control by RNA-seq. 


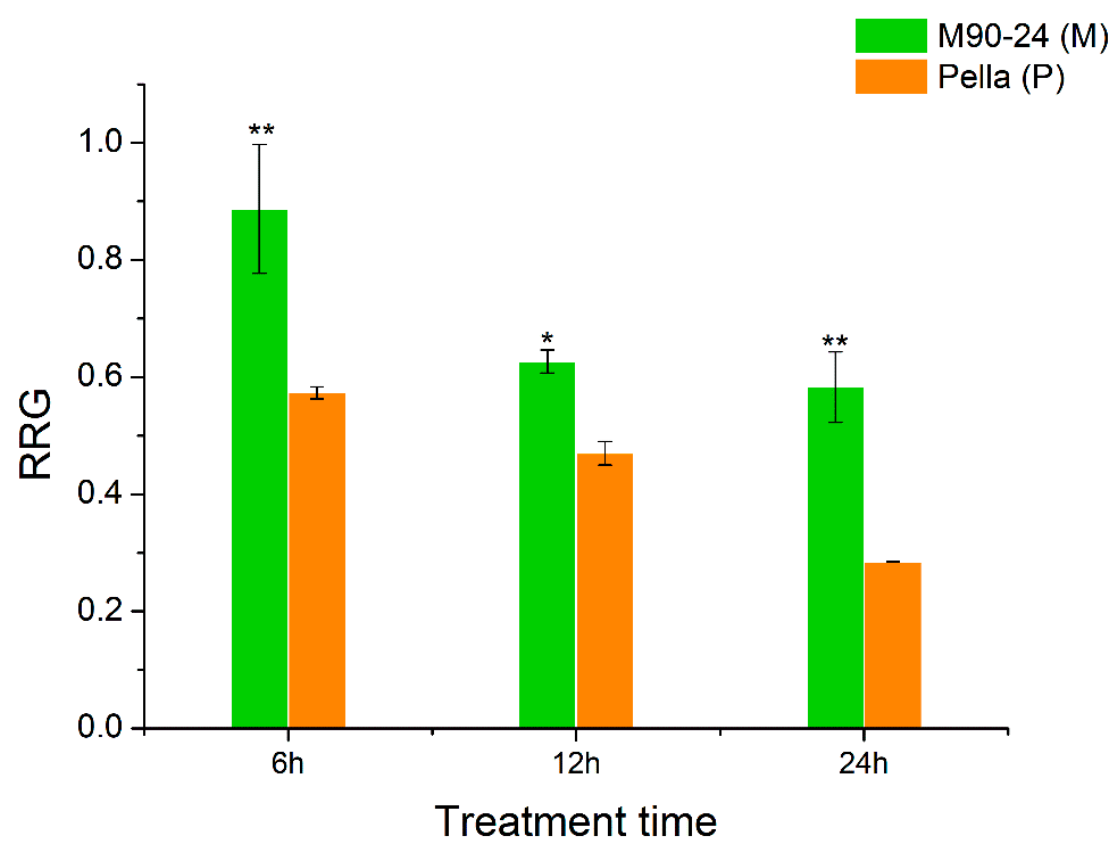

Figure 1. The relative root growth (RRG) of two soybean varieties (primary roots) at 6, 12 and $24 \mathrm{~h}$ of $\mathrm{Al}$ stress. The control and $\mathrm{Al}$ treatment contain 0 and $25 \mu \mathrm{M} \mathrm{AlCl}_{3}, \mathrm{pH}=4.3$, respectively. Data represent mean \pm standard error from three biological replications; ${ }^{*}$ and ${ }^{*}$ indicate significant difference in RRG between two soybean varieties at the 0.05 and 0.01 level, respectively.

\subsection{RNA-seq Data Quality, Assembly and Annotation}

A total of $83.40 \mathrm{~GB}$ raw reads and 79.20 GB high-quality clean data were obtained for 16 samples, with the average of $4.89 \mathrm{~GB}$ clean data per sample. On average, $95.27 \%$ clean reads had Phred-like quality scores at the Q20 level (an error probability of 1\%), and 91.71\% at the Q30 level (an error probability of $0.1 \%$ ). The average GC contents were about $45.40 \%$. After assembly, the 16 sets of clean reads were mapped to the soybean reference genome (Wm82.a2.v1). Among the 16 samples, $91.07 \%$ to $94.22 \%$ of the clean reads were mapped to the soybean genome, and the uniquely mapped percentage ranged from $84.82 \%$ to $92.95 \%$ (Tables S1 and S2). The gene coverage (genes with FPKM $\geq 0.01$ ) started to show saturation when approximately more than 5 million clean reads were obtained by RNA-seq (Figure S1A), while the average number of clean reads for our 16 samples was 17.43 million, which exceeded the saturation threshold. The sequencing reads were uniformly distributed in the relative position ( $5^{\prime}$ to $\left.3^{\prime}\right)$ in genes (Figure S1B). These analyses indicate that the quality of our RNA-seq data was high and the sequencing depth was sufficient for further analysis.

\subsection{Differentially Expressed Genes (DEGs) in Soybean Roots in Response to Al Stress}

By using the criteria of false discovery rate $(F D R)<0.05$ and $\mid \log _{2}$ (fold change) $\mid>1$, the differentially expressed genes (DEGs) between $\mathrm{Al}$ stress and control at 6 and $12 \mathrm{~h}$ in the roots of two soybean varieties were identified, respectively. There were 1905 and 4309 DEGs between Al stress and control at 6 and $12 \mathrm{~h}$ in M, respectively, while there were 633 and 2844 DEGs between Al stress and control at 6 and $12 \mathrm{~h}$ in P, respectively (Figure 2). In the Al-tolerant soybean variety M, there were 633 up-regulated and 1272 down-regulated DEGs between Al stress and control at $6 \mathrm{~h}$, respectively, while there were 3176 up-regulated and 1133 down-regulated DEGs between $\mathrm{Al}$ stress and control at $12 \mathrm{~h}$, respectively (Table S3). In the Al-sensitive soybean variety $\mathrm{P}$, there were only 169 up-regulated and 464 down-regulated DEGs between Al stress and control at $6 \mathrm{~h}$, respectively, and 2189 up-regulated and 655 down-regulated DEGs between Al stress and control at $12 \mathrm{~h}$, respectively (Table S3). Fifteen and 21 pathways were enriched in up- or down-regulated genes in M, respectively, while 14 and 16 pathways were enriched in up- or down-regulated genes in P, respectively (Table S4). 
Arginine and proline metabolism (ko00330) as well as photosynthesis (ko00195) were only enriched in the up-regulated genes in the Al tolerant soybean variety M (Table S4). Circadian rhythm-plant (ko04712), flavonoid biosynthesis (ko00941), nitrogen metabolism (ko00910), phenylalanine metabolism (ko00360), plant-pathogen interaction (ko04626), and sulfur metabolism (ko00920) were enriched only in up-regulated genes in both soybean varieties. Six pathways including amino sugar and nucleotide sugar metabolism (ko00520), diterpenoid biosynthesis (ko00904), DNA replication (ko03030), mismatch repair (ko03430), pentose and glucuronate interconversions (ko00040), as well as valine, leucine and isoleucine degradation (ko00280), were enriched only in down-regulated genes in both soybean varieties. Phenylalanine biosynthesis (ko00940) was enriched in both up- and down- regulated genes in both soybean varieties (Table S4).

$6 \mathrm{~h}$

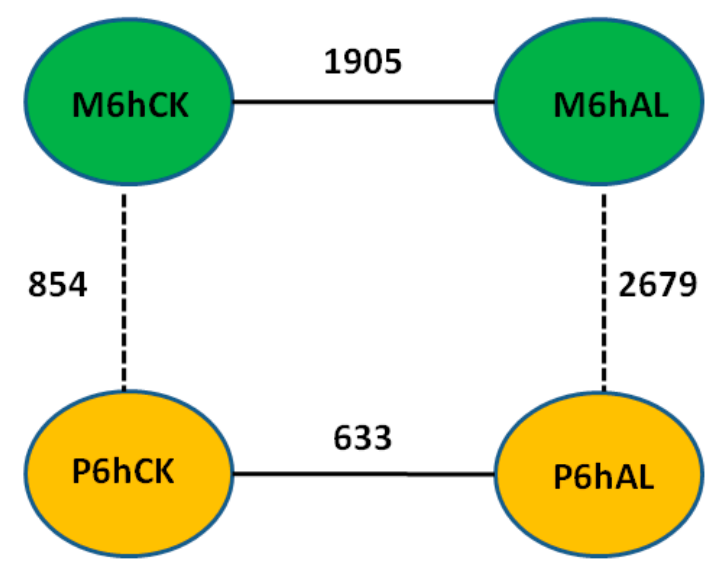

$12 \mathrm{~h}$

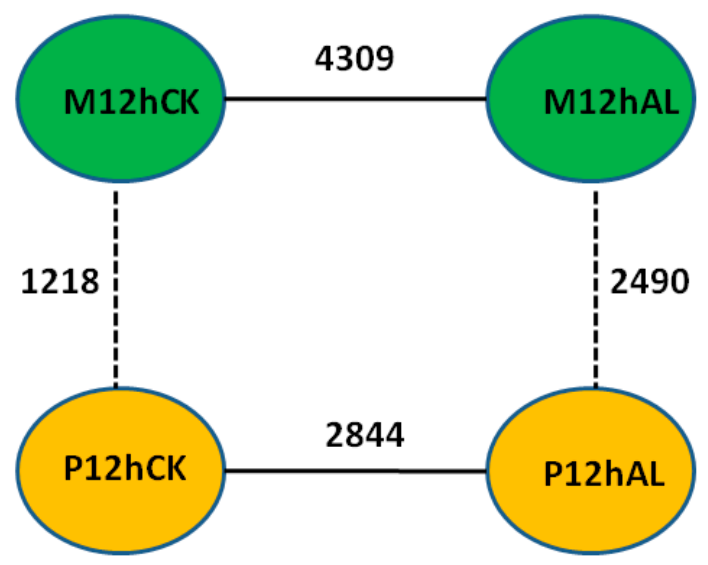

Figure 2. Diagram of the differentially expressed genes (DEGs) identified from different comparisons between samples from the two soybean varieties under $\mathrm{Al}$ stress $\left(25 \mu \mathrm{M} \mathrm{AlCl}_{3}, \mathrm{pH}=4.3\right)$ and control $\left(0 \mu \mathrm{M} \mathrm{AlCl}_{3}, \mathrm{pH}=4.3\right)$ at 6 and $12 \mathrm{~h}$.

\subsection{DEGs between Two Soybean Varieties}

The DEGs between two soybean varieties, $\mathrm{M}$ and $\mathrm{P}$, were also identified using the criteria of $F D R<0.05$ and $\mid \log _{2}$ (fold change) $\mid>1$. Under control (CK) conditions, there were 854 and 1218 DEGs between two soybean varieties at 6 and 12 h, respectively, while 2679 and 2490 DEGs were found between two varieties under $\mathrm{Al}$ stress at 6 and $12 \mathrm{~h}$, respectively (Figure 2). These results show that at the same time point, there were more DEGs between two soybean varieties under $\mathrm{Al}$ stress than control condition, which is likely due to the changes in gene expression upon Al stress. Under control conditions, there were 573 higher-expression and 281 lower-expression genes in $\mathrm{M}$ than $\mathrm{P}$ at $6 \mathrm{~h}$, respectively, while 749 higher-expression and 469 lower-expression genes in $\mathrm{M}$ than $\mathrm{P}$ at $12 \mathrm{~h}$, respectively (Table S5). Under Al stress, there were 1574 higher-expression and 1105 lower-expression genes in $\mathrm{M}$ than $\mathrm{P}$ at $6 \mathrm{~h}$, respectively, while there were 1687 higher-expression and 803 lower-expression genes in $\mathrm{M}$ than $\mathrm{P}$ at $12 \mathrm{~h}$, respectively (Table S5).

\subsection{Identification of Candidate Genes Related to Al Tolerance in Soybean}

In detail, 3336 and 2244 genes were up-regulated by $\mathrm{Al}$ stress in $\mathrm{M}$ and $\mathrm{P}$, respectively, among which 1799 Al-up-regulated genes were specific to $\mathrm{M}$ and 1537 Al-up-regulated genes overlapped between M and P (Figure 3A). Among the 1537 overlapped Al-up-regulated genes, 1050 genes were up-regulated more in $\mathrm{M}$ than $\mathrm{P}$. Together, 2849 Al-up-regulated genes, including 1799 specific to $\mathrm{M}$ and 1050 genes overlapped between $\mathrm{M}$ and $\mathrm{P}$ but with more fold change in $\mathrm{M}$ than $\mathrm{P}$, were designated as M-up-selected (Figure 3A, Table S6). Similarly, 1869 Al-down-regulated genes, including 1505 specific to $\mathrm{M}$ and 364 overlapped between $\mathrm{M}$ and $\mathrm{P}$ genes with more down-regulation in $\mathrm{M}$ than $\mathrm{P}$, were designated as M-down-selected (Figure 3B, Table S7). 
In order to identify the most possible Al-responsive candidate genes for soybean tolerance to $\mathrm{Al}$ toxicity, the genes in $\mathrm{M}$-up-selected that also showed higher expression levels in $\mathrm{M}$ than $\mathrm{P}$ under $\mathrm{Al}$ stress at both time points were further selected (354 genes) and designated as M-up-high (Figure 3C, Table S8), and the genes in M-down-selected that showed lower expression levels in $\mathrm{M}$ than $\mathrm{P}$ under $\mathrm{Al}$ stress at both time points (43 genes) were designated as M-down-low (Figure 3D, Table S9).

A

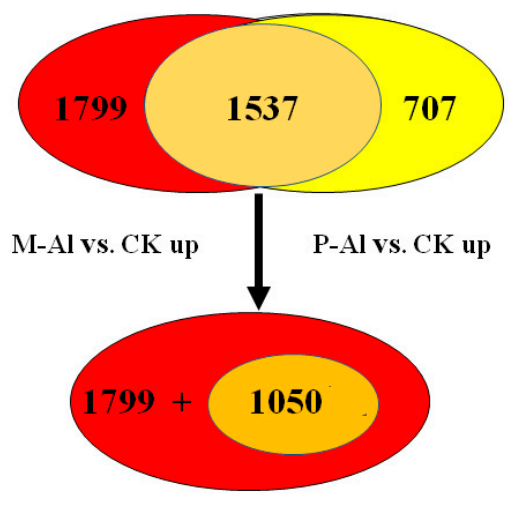

M-up-selected (2849)

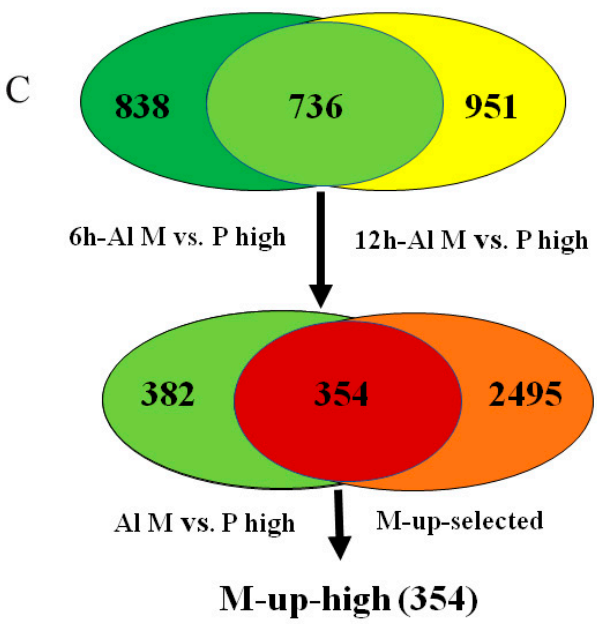

B

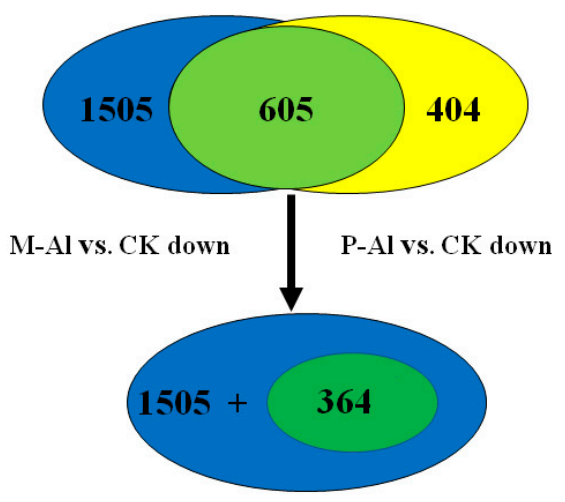

M-down-selected (1869)

$\mathrm{D}$

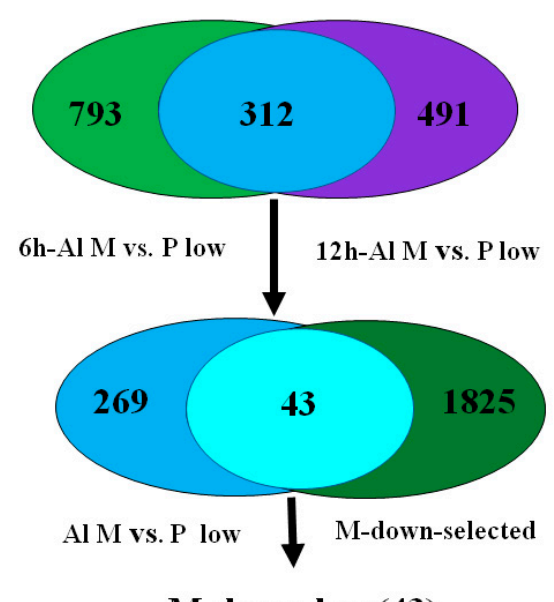

M-down-low (43)

Figure 3. The selection procedure for Al-tolerance related genes in the lists of M-up-selected, M-down-selected, M-up-high and M-down-low. (A) The M-up-selected list includes 2849 Al-induced genes specific to M (1799) or with more up-regulation in M than P (1050). (B) The M-down-selected list includes 1869 Al-repressed genes specific to M (1505) or with more down-regulation in M than P (364). (C) The M-up-high list includes 354 genes with higher relative expression levels in $\mathrm{M}$ than $\mathrm{P}$ under $\mathrm{Al}$ treatment and more up-regulation by $\mathrm{Al}$ in $\mathrm{M}$ than $\mathrm{P}$. (D) The M-down-low list includes 43 genes with lower relative expression levels in $\mathrm{M}$ than $\mathrm{P}$ under $\mathrm{Al}$ treatment and more down-regulation by $\mathrm{Al}$ in $\mathrm{M}$ than $P$.

\subsection{Gene Ontology (GO) Enrichment of Candidate Al Tolerance Genes in Soybean}

We used agriGo $(p<0.01, F D R<0.05)$ to perform $\mathrm{GO}$ enrichment analysis of candidate $\mathrm{Al}$ tolerance genes in soybean variety $\mathrm{M}$. Genes in M-up-selected are significantly enriched in the biological processes (Figure S2) such as DNA-dependent regulation of transcription (GO:0006355, FDR $=1.93 \times 10^{-16}$ ) and protein amino acid phosphorylation (GO:0006468, $F D R=1.25 \times 10^{-8}$ ). There are 207 genes in the GO term of DNA-dependent regulation of transcription, which are enriched in AP2, HB-other, HSF, NAC and WRKY transcription factors (Figure 4). While the M-down-selected genes are significantly enriched in the biological processes (Figure S3) such as DNA replication (GO:0006260, FDR $=1.59 \times 10^{-7}$ ) and 
oxidation reduction (GO:0055114, $F D R=1.59 \times 10^{-7}$ ), the genes in M-up-high are significantly enriched in the GO terms (Figure S4) related to cellular glucan metabolic process (GO:0006073, FDR $=3.76 \times 10^{-6}$ ) and regulation of cellular process (GO:0050794, $\left.F D R=3.88 \times 10^{-5}\right)$. No significantly enriched GO terms were found in M-low-down since there are only 43 DEGs in it. There are 11 genes (Table S10) in the enriched GO term of cellular glucan metabolic process (GO:0006073), including five genes encoding cellulose synthase and six genes encoding xyloglucan endotransglycosylase (XET). There are 43 genes in the enriched GO term of regulation of cellular process (GO:0050794), which includes 30 genes related to DNA-dependent regulation of transcription (GO:0006355, FDR $=2.48 \times 10^{-4}$ ) such as the AP2 domain, AUX/IAA family, NAM, and WRKY DNA binding proteins (Table S11). These 11 and 43 genes showed up-regulated expression by $\mathrm{Al}$ in the $\mathrm{Al}$-tolerant soybean variety $\mathrm{M}$ and higher transcript levels in M than P under Al stress (Figure 5), as seen in the other DEGs in M-up-high (Table S8).

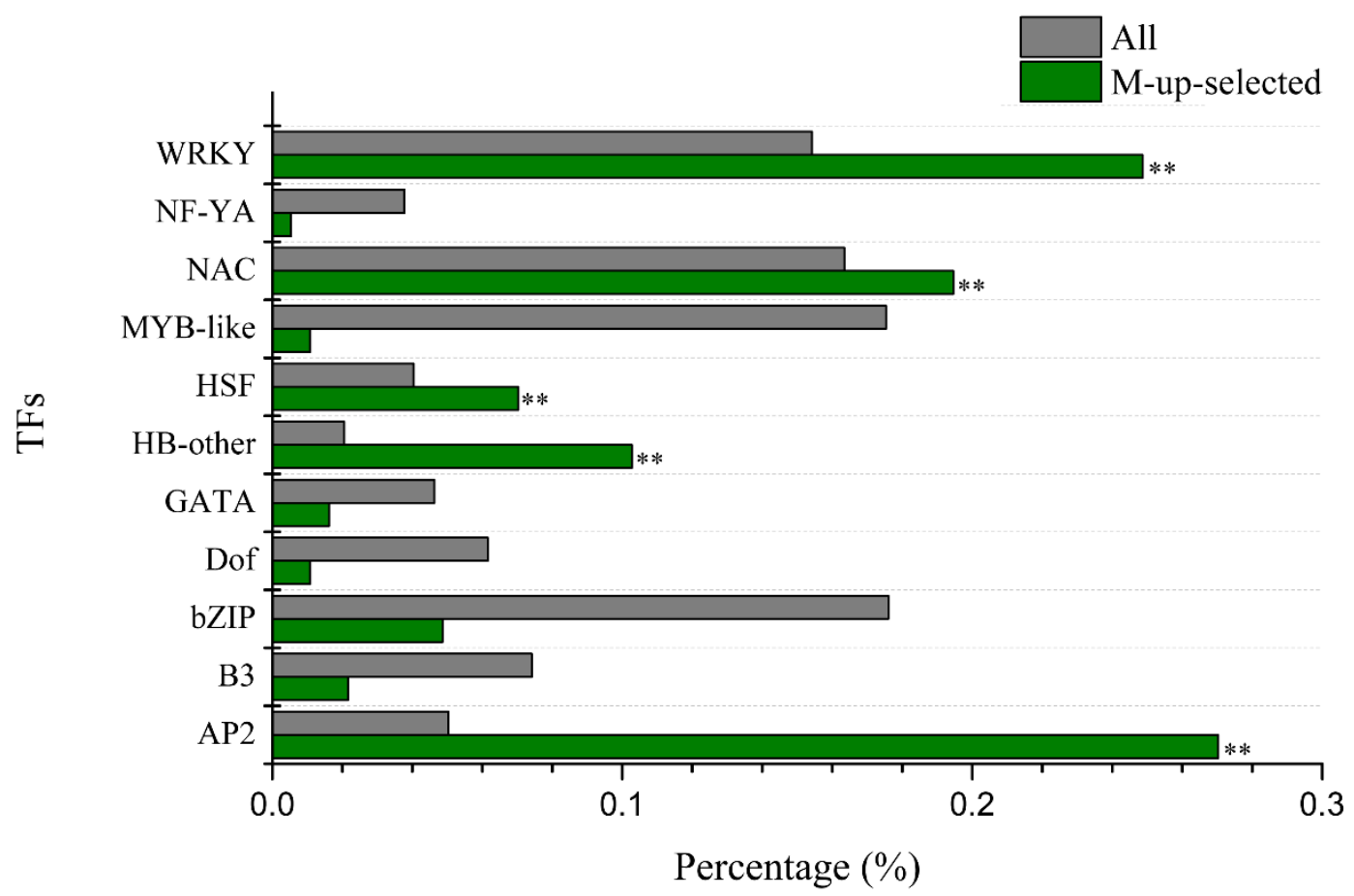

Figure 4. Enrichment of the transcription factor (TF) families among the M-up-selected genes. The percentage of TF families in M-up-selected genes and all TFs in soybean genome was shown as green bars and grey bars, respectively. ${ }^{* *}$ indicate significant enrichment at 0.01 level. 


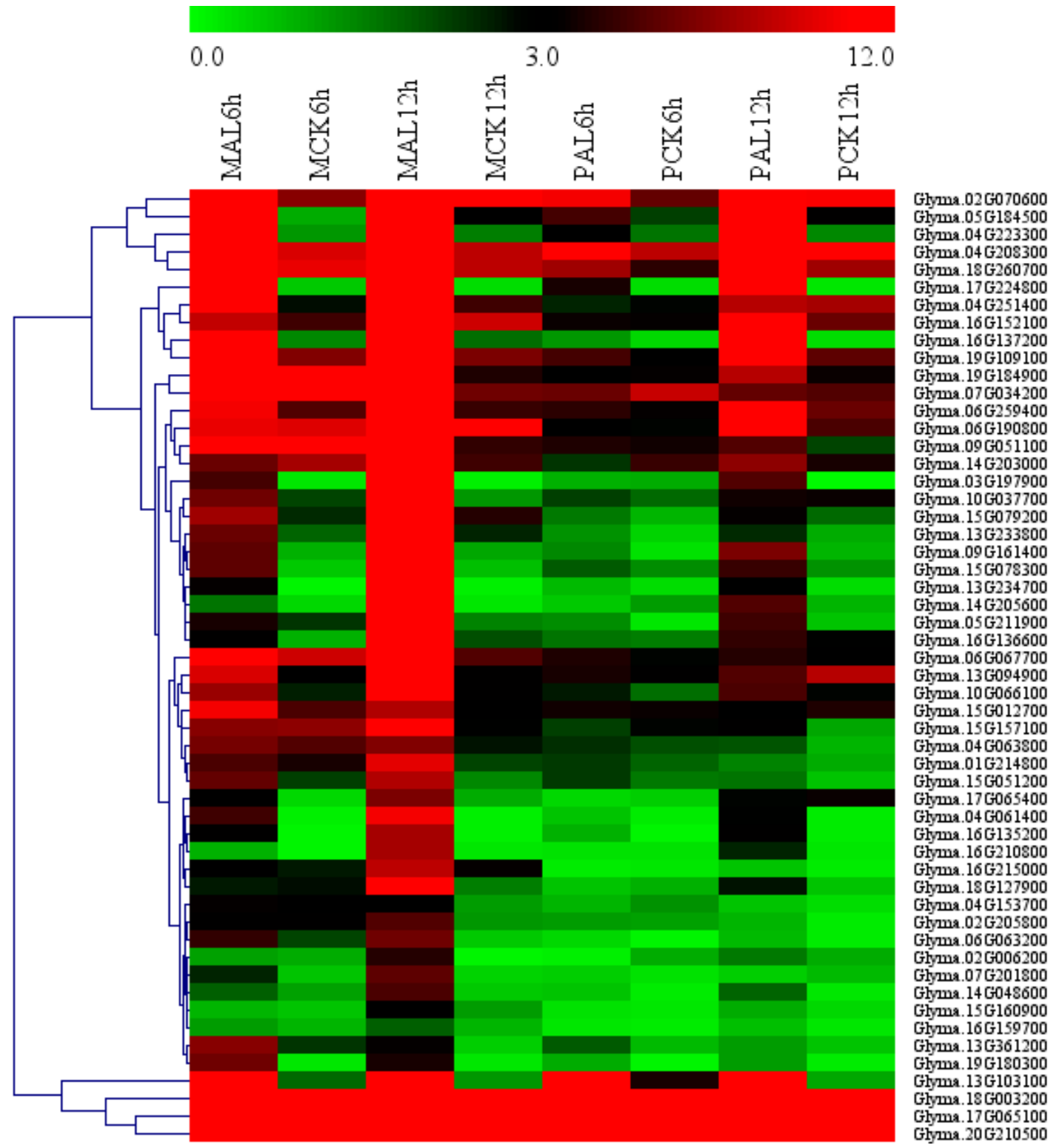

Figure 5. Heatmap of the genes in the enriched GO terms of cellular glucan metabolic process (0006073) and regulation of cellular process (GO:0050794) in M-up-selected list. Heatmap was plotted using Mev4.9 software. Hierarchical clustering of genes was done by complete method with Euclidean distance. The gene expression levels were transformed by $\log _{2}(\mathrm{FPKM}+1)$ and the values were centered and scaled in row direction. $\mathrm{X}$-axis, samples; $\mathrm{Y}$-axis, gene names.

\subsection{Identification of Hub Genes through Co-Expression Network}

The co-expression network of the genes in the M-up-selected list (Table S6) was analyzed and a total of six modules were identified (Figure S5). Among these modules, the green module (containing 267 genes) showed a significant $\left(p=7 \times 10^{-5}\right)$ positive correlation $(r=0.97)$ with RRG. To screen the key genes from the green module, we further identified the hub genes via co-expression network in green module. One hub gene, Glyma.02G205800, has the highest module membership value, which encodes a cellulose synthase. We then constructed the visual co-expression network of this hub gene (Figure 6) and found that its co-expressed genes include genes encoding AUX/IAA transcription factor (Glyma.20G210500), bZip transcription factor (Glyma.05G182500), cell wall related proteins such as cellulose synthases (Glyma.04G063800 and Glyma.04G153700), XET (Glyma.17G064900, Glyma.18G003200 and Glyma.19G184900), polysaccharide 
biosynthesis-related proteins (Glyma.16G001600 and Glyma.17G169200), zinc finger proteins (Glyma.06G076600, Glyma.14G177900, Glyma.15G072700 and Glyma.18G074600), and others. Zinc finger proteins, bZip transcription factors, cell wall-related proteins and AUX/IAA transcription factors have been shown to be associated with $\mathrm{Al}$ tolerance [47-50], which indicates that the hub gene Glyma.02G205800, together with its co-expressed genes, might play important roles in soybean tolerance to $\mathrm{Al}$ toxicity.

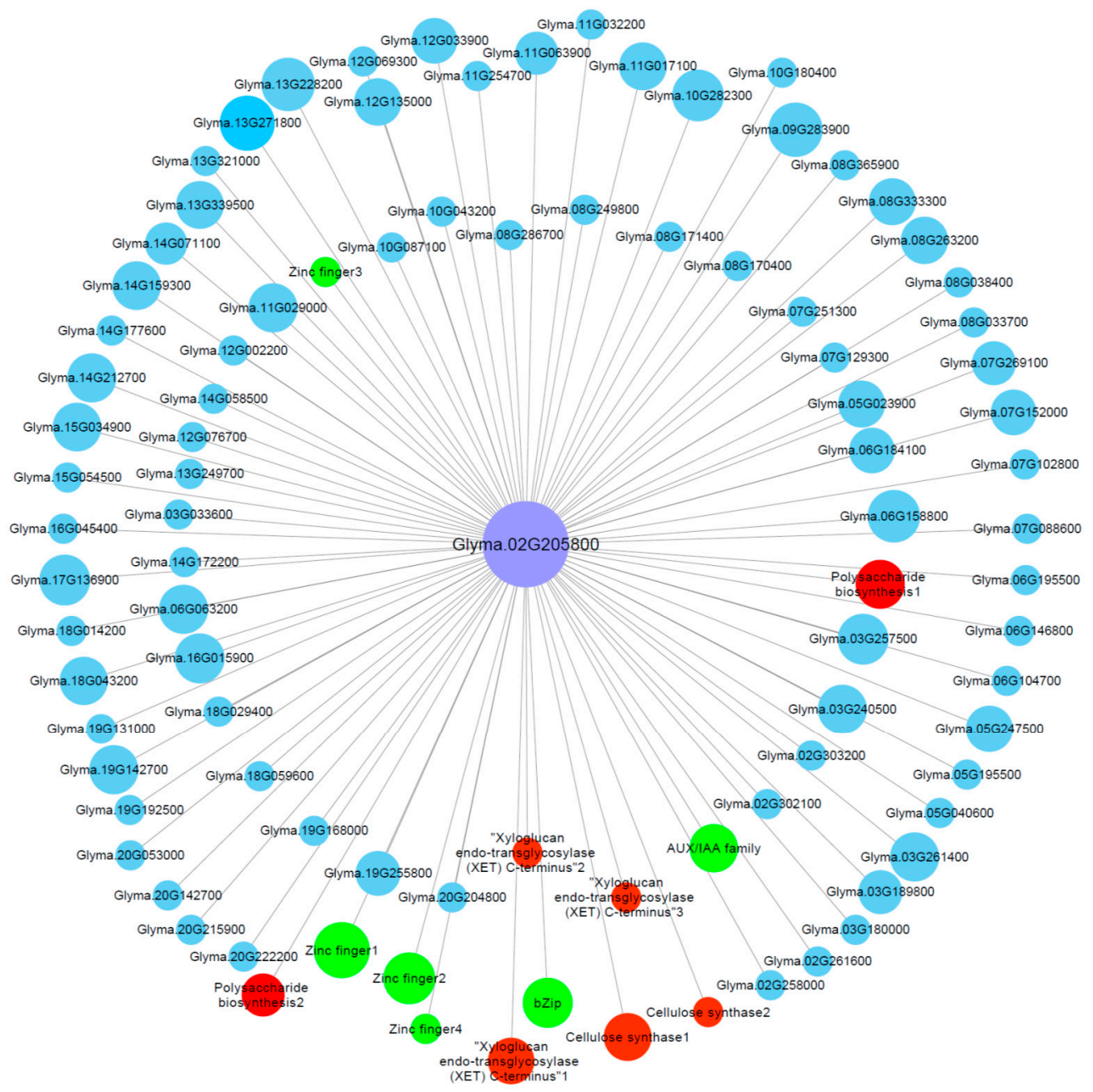

Figure 6. Gene co-expression network for Glyma.02G205800 (encoding cellulose synthase) in the green module. Only the genes (nodes) with the module membership value greater than 0.3 are shown. The nodes in red represent cell wall related genes, while the nodes in green represent known Al-tolerance related genes.

\subsection{Validation of RNA-seq Data by Quantitative Real Time PCR (qRT-PCR) Analysis}

The relative gene expression levels from RNA-seq were verified by qRT-PCR using 12 DEGs (Table S12), including six genes from M-up-high (two cellulose synthase genes, three XET genes, and one AUX/IAA family gene), three genes from enriched KEGG pathways and three genes from M-down-low. The expression profiles of these 12 genes showed similar patterns by RNA-seq and qRT-PCR (Figure 7A,B), and a high consistency was obtained between two methods (Figure 7C). 
A

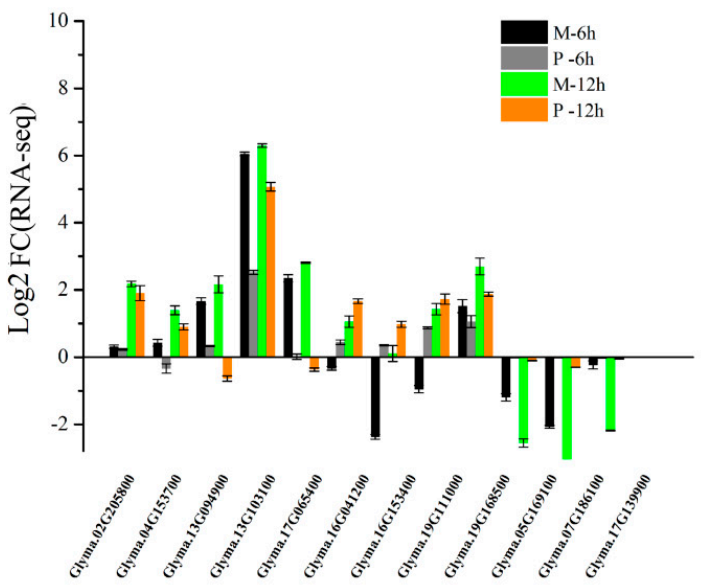

B

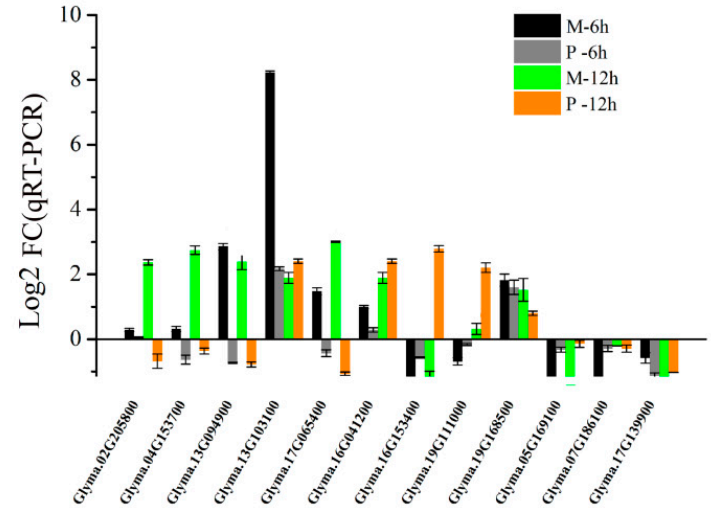

C

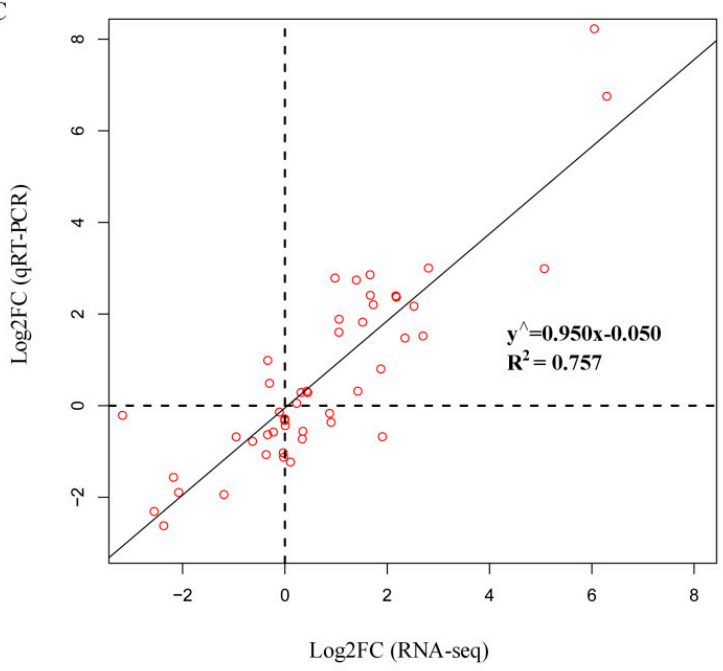

Figure 7. Comparison of the relative expression levels of 12 genes by RNA-seq and qRT-PCR analysis. (A) Relative expression of 12 genes at 6 and $12 \mathrm{~h}$ after $25 \mu \mathrm{M} \mathrm{AlCl} 3$ (pH 4.3) stress compared with control $(0 \mu \mathrm{M} \mathrm{AlCl}, \mathrm{pH} 4.3)$ by RNA-seq. (B) Relative expression of 12 genes at 6 and $12 \mathrm{~h}$ after $25 \mu \mathrm{M} \mathrm{AlCl} \mathrm{Al}_{3}(\mathrm{pH}$ 4.3) stress compared with control $(0 \mu \mathrm{M} \mathrm{AlCl}, \mathrm{pH} 4.3)$ by qRT-PCR. (C) The correlation analysis between qRT-PCR and RNA-seq using $\log _{2}$ FC. FC represents fold change. Glyma.02G205800 and Glyma.04G153700 encode cellulose synthases; Glyma.13G094900, Glyma.13G103100 and Glyma.17G065400 encode xyloglucan endo-transglycosylases (XET); Glyma.16G041200, Glyma.16G041200, and Glyma.19G111000 encode glutamate dehydrogenases; Glyma.19G168500 encodes an auxin-induced protein (AUX/IAA family); Glyma.05G169100 belongs to the cupin family with nutrient reservoir activity; Glyma.07G186100 encodes a branched chain aminotransferase; Glyma.17G139900 encodes a seed storage protein. 


\subsection{Role of Cellulose Synthase Genes in Soybean Tolerance to Al Toxicity}

The relative expression levels of five cellulose synthase genes were up-regulated by Al stress and were higher in $\mathrm{M}$ than $\mathrm{P}$ (Table S10). Therefore, we investigated the relationship between cellulose production and $\mathrm{Al}$ tolerance. We used the cellulose biosynthesis inhibitor (CBI), indaziflam, to test if inhibition of cellulose production leads to decreased Al tolerance (RRG) in soybean. Indaziflam showed strong CBI activity in the dicotyledonous plant (Arabidopsis thaliana L.), which could inhibit the production of cellulose less than $1 \mathrm{~h} \mathrm{[51].} \mathrm{We} \mathrm{used} \mathrm{three} \mathrm{concentrations} \mathrm{of} \mathrm{indaziflam,} 0.06$, 0.08 and $0.10 \mathrm{nM}$, to test their effect on the RRG of soybean under $\mathrm{Al}$ stress and control conditions. Under control condition $\left(0 \mu \mathrm{M} \mathrm{AlCl}_{3}\right)$, the RRG was simulated at 0.06 and $0.08 \mathrm{nM}$ indaziflam, but was not significantly affected at $0.10 \mathrm{nM}$ comparing with $0 \mathrm{nM}$ indaziflam (Figure 8A). Under $25 \mu \mathrm{M}$ $\mathrm{AlCl}_{3}$ stress (Figure $8 \mathrm{~B}$ ), the RRG decreased significantly by $0.06,0.08$ and $0.10 \mathrm{nM}$ indaziflam in a dosage-dependent manner, comparing with $0 \mathrm{nM}$ indaziflam, indicating that indaziflam further reduced RRG under $\mathrm{Al}$ stress, which coincides with the fact that the expression levels of the five cellulose synthase genes in Al-sensitive variety $\mathrm{P}$ are lower than the Al-tolerant variety $\mathrm{M}$. These results therefore support our hypothesis that decreased cellulose production leads to more $\mathrm{Al}$ induced inhibition of root growth (more sensitive to $\mathrm{Al}$ toxicity) in soybean.

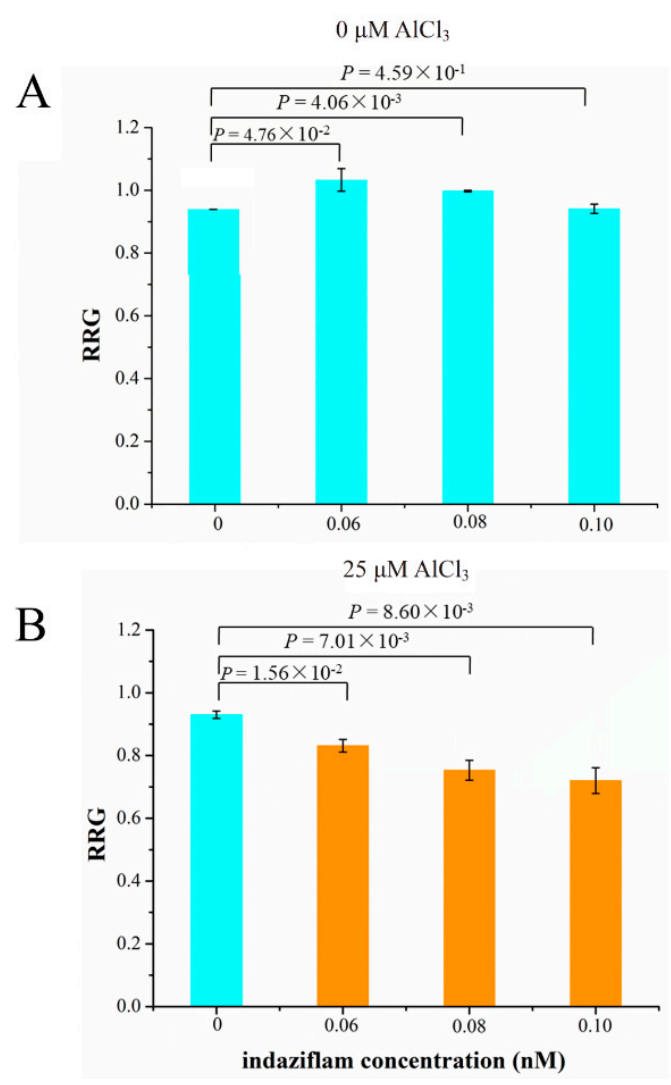

Figure 8. The effect of cellulose biosynthesis inhibitor (indaziflam) on the relative root growth (RRG) of soybean primary roots under $0(\mathbf{A})$ or $25 \mu \mathrm{M} \mathrm{AlCl}_{3}$ (B). $P$ values above the bars indicate the significant levels by Student's $t$-tests.

\section{Discussion}

The most significant effect of $\mathrm{Al}$ toxicity is the inhibition of root elongation, and the root apex is the most obvious area of $\mathrm{Al}$ damage [21,52]. In our study, soybean variety $\mathrm{M}$ had the average RRG of $67 \%$ and $\mathrm{P}$ had the average RRG of $30 \%$ after $24 \mathrm{~h}$ of $25 \mu \mathrm{M} \mathrm{AlCl} \mathrm{Al}_{3}$ treatment (Figure 1). In order to identify $\mathrm{Al}$ tolerance candidate genes and the possible molecular basis of $\mathrm{Al}$ tolerance in soybean, we performed a comparative transcriptome analysis of the root tips under $\mathrm{Al}$ stress and control between 
$\mathrm{M}$ (Al-tolerant) and $\mathrm{P}$ (Al-sensitive). We proposed that the following factors might be related to $\mathrm{Al}$ tolerance in soybean.

Cellulose, as an important component of the plant cell wall, plays a critical role against abiotic stresses, including $\mathrm{Al}$ toxicity. Al stress disturbs the cellulose synthase conformation [53], which results in lowering the cellulose production, indicating that $\mathrm{Al}$ induced growth inhibition might be partially dependent on the decreased cellulose. Indaziflam, a cellulose biosynthesis inhibitor (CBI), can deplete the cellulose synthase complexes on the plasma membrane, finally blocking the cellulose production [51]. CBI-treated plants exhibited severe growth inhibition, accompanied by the swelling of root tip cells [51]. In this study, we found that indaziflam treatment led to more Al-induced inhibition of root growth (more Al-sensitive) in soybean. These results suggest that cellulose production plays an important role in soybean tolerance to $\mathrm{Al}$ toxicity. In recent years, it has been found that the content of cellulose in plant roots changes under environmental stresses, such as temperature $[54,55]$ and salt stress [56,57]. Teraoka et al. [53] found that under Al stress, the cell wall cellulose content in the wheat root tip cells of an Al-sensitive cultivar decreased more than in those of the Al-tolerant cultivar, accompanied by apical swelling and inhibition of root growth. The changes in the cellulose content of soybean roots under $\mathrm{Al}$ stress have not been reported, and we will continue to conduct in-depth studies on the role of cellulose synthase and cellulose content in soybean tolerance to $\mathrm{Al}$ stress in the future, and the changes in root cell expansion under Al stress will also be observed by microscopy.

In addition to cellulose synthase, there were six XET genes in the enriched GO term of cellular glucan metabolic process (GO:0006073) among the M-up-high list, which showed up-regulated expression by $\mathrm{Al}$ in $\mathrm{M}$ and higher transcript levels in $\mathrm{M}$ than $\mathrm{P}$ under $\mathrm{Al}$ stress. XET is involved in cell wall extension and participates in cell expansion [58]. Under Al stress, Al binds to various cell wall components, which influences the symplastic cell functions of the cell wall [21]. In this study, compared with Al-sensitive soybean variety $\mathrm{P}$, higher XET gene expression in Al-tolerant $\mathrm{M}$ may reduce the Al-toxicity caused by reduced elasticity and plasticity of cell wall.

Because soybean variety $\mathrm{M}$ is more tolerant to $\mathrm{Al}$ stress than $\mathrm{P}$ (Figure 1), the Al-responsive DEGs that were specific to $\mathrm{M}$ or genes that were more differentially expressed (up or down regulated) in $\mathrm{M}$ than $\mathrm{P}$ would be the first group of candidates related to $\mathrm{Al}$ tolerance (Figure $3 \mathrm{~A}, \mathrm{~B})$. These candidate genes could be further narrowed down to the genes that also showed higher expression levels in $\mathrm{M}$ than $\mathrm{P}$ for up-regulated genes or lower expression levels in $\mathrm{M}$ than $\mathrm{P}$ for down-regulated genes under $\mathrm{Al}$ stress at both time points (Figure 3C,D). In the M-up-selected genes that showed either specificity to $\mathrm{M}$ or more up-regulation in M than $\mathrm{P}$, the GO:0006355 term (DNA-dependent regulation of transcription) was significantly enriched. There were 207 DEGs in this term, including 185 transcription factors, which were divided into 11 groups (AP2, B3, bZIP, Dof, GATA, HB-other, HSF, MYB-like, NAC, NF-YA, and WRKY). Among these, AP2, HB-other, HSF, NAC and WRKY transcription factors were significantly enriched (Figure 4).

The most abundant transcription factor family in the M-up-selected gene list was AP2, with a total number of 50 genes. The expression levels of $45 \mathrm{AP} 2$ genes were up-regulated more in the Al-tolerant variety $\mathrm{M}$ than that in sensitive variety $\mathrm{P}$ at $12 \mathrm{~h}$ after $\mathrm{Al}$ treatment, and the fold change of the remaining five AP2 genes was higher in $\mathrm{M}$ than $\mathrm{P}$ after $6 \mathrm{~h} \mathrm{Al}$ treatment. Although there is no direct evidence that AP2 transcription factor is associated with Al tolerance, it has been found that AP2 / ERF transcription factors are involved in various signaling pathways such as abscisic acid (ABA), salicylic acid (SA), jasmonic acid, and ethylene [59-62]. ABA and SA have been shown to play important roles in $\mathrm{Al}$ tolerance. It has been demonstrated that elevated levels of $\mathrm{ABA}$ can promote $\mathrm{Al}$ detoxification in buckwheat [63], while exogenous SA can improve the tolerance to Al stress [60] and reduce the oxidative stress caused by $\mathrm{Al}$ toxicity [64].

There were 46 genes encoding WRKY transcription factors in the M-up-selected gene list, and 41 of them were up-regulated more in the Al-tolerant variety $\mathrm{M}$ than that in the sensitive variety $\mathrm{P}$ at $12 \mathrm{~h}$ of $\mathrm{Al}$ stress, and the fold change of remaining five genes was higher in $\mathrm{M}$ than that in $\mathrm{P}$ at $6 \mathrm{~h}$ of $\mathrm{Al}$ treatment. It has been found that WRKY 69 was induced by $\mathrm{Al}$ in maize and expressed higher 
in $\mathrm{Al}$ tolerant line than Al-sensitive line [65]. Another gene AtWRKY33 was also up-regulated by $\mathrm{Al}$ in Arabidopsis [66]. The role of WRKY transcription factors in soybean tolerance to Al toxicity needs further investigation.

Fifteen genes encoding the AUX/IAA family were found in the M-up-selected gene list. AUX/IAA proteins participate in the auxin signaling pathway and play important roles in plant development and stress tolerance $[49,50]$. It has been shown that $\mathrm{Al}$ induced auxin accumulation in soybean roots, and IAA enhanced the expression of GMMATE under Al stress [64]. In addition, Al-induced endogenous IAA accumulation significantly correlated with malate exudation, and exogenous treatment with $10 \mu \mathrm{M}$ IAA or $30 \mu \mathrm{M}$ N-1-naphthyl-phthalamc acid (NPA, its efflux transport inhibitor) enhanced or decreased malate efflux in wheat roots, thus demonstrating a possible role of IAA in alleviating Al toxicity [67].

In addition to the above genes in the enriched GO terms, four genes encoding ABC transporters (Glyma.06G0191400, Glyma.08G106900, Glyma.08G342600, Glyma.16G078100) and three MATE genes (Glyma.02G090100, Glyma.10G267700, Glyma.16G157300) were also found in the M-up-selected list (Table S6), which showed more up-regulation in the Al-tolerant $\mathrm{M}$ than Al-sensitive P. Studies have shown that $\mathrm{ABC}$ transporter and MATE genes play important roles in plant tolerance to Al toxicity. For example, two ABC transporter genes (STAR1 and STAR2) were induced by $\mathrm{Al}$ and required for $\mathrm{Al}$ detoxification in rice [68]. The SbMATE1 gene in sorghum was induced by Al and enhanced root citrate exudation [35]. Therefore, the four ABC transporter genes and three MATE genes in the M-up-selected list might also play important roles in soybean tolerance to Al toxicity. The GmALMT1 gene has been found to be associated with Al tolerance in soybean [33]. However, ALMT genes did not appear in our M-up-selected list, which suggests that different soybean varieties might have different genes and mechanisms to confer Al tolerance.

Previously, it has been reported that ABC transporter, ALMT, cellulose synthase, MATE, zinc finger proteins might be associated with Al-tolerance in Arabidopsis, maize, buckwheat, and wheat [26,28,30,36,69]. In soybean, several Al-tolerance related genes have been reported, such as ALMT, MATE and STOP1 [33,70,71]. However, so far, there have been no reports on the role of cellulose genes in soybean $\mathrm{Al}$ tolerance, and therefore our study will shed light on the genes and mechanisms underlying soybean Al tolerance.

\section{Materials and Methods}

\subsection{Plant Growth Conditions and Stress Treatment}

Seeds of two soybean varieties, M90-24 (M) and Pella (P), were obtained from the National Center for Soybean Improvement, Nanjing, China. Soybean seeds were washed thoroughly with tap water for $1 \mathrm{~min}$, then 3 times with distilled water, and germinated in clean sand for three days at $26{ }^{\circ} \mathrm{C}$ in the dark. After germination, uniform seedlings were selected and transferred to $500 \mathrm{~mL}$ plastic beakers (six seedlings per beaker) filled with $0.5 \mathrm{mM} \mathrm{CaCl}_{2}$ solution ( $\mathrm{pH} 4.3$ ) for $24 \mathrm{~h}$. Then the seedlings were subjected to $0.5 \mathrm{mM} \mathrm{CaCl}_{2}$ solution ( $\mathrm{pH} 4.3$ ) containing 0 (control) or $25 \mu \mathrm{M} \mathrm{AlCl}_{3}$ for 6,12 or $24 \mathrm{~h}$. There were four beakers for each soybean variety, two for control $(0 \mu \mathrm{M} \mathrm{AlCl}, \mathrm{pH} 4.3)$ and the other two for $\mathrm{Al}$ treatment $\left(25 \mu \mathrm{M} \mathrm{AlCl}_{3}, \mathrm{pH} 4.3\right)$. Plants were grown in a well-controlled growth room with the temperature regime of $28 / 22^{\circ} \mathrm{C}$ (day/night), photoperiod of $14 / 10 \mathrm{~h}$ (light/dark), light intensity of $45,000 \mathrm{~lx}$ and relative humidity of $30-40 \%$. Three independent experiments were performed, and there were two replications within each experiment, with six seedlings per treatment per replication.

\subsection{Root Length Measurement and Relative Root Growth}

Length of the primary root for each soybean seedling was measured using a ruler at $0,6,12$ and $24 \mathrm{~h}$ of treatment (the roots were immersed in sterile water when measuring to avoid dehydration damage). The Al tolerance can be indicated by the relative root growth (RRG) as described previously [72]. The RRG can be calculated by the following formula: 


$$
\begin{aligned}
& R G=R L_{t}-R L_{0} \\
& R R G=R G_{A l} R G_{\mathcal{C}}
\end{aligned}
$$

In Equation (1), root growth (RG) is the difference between the average root length after 6, 12, or $24 \mathrm{~h}$ of treatment $\left(\mathrm{RL}_{\mathrm{t}}\right)$ and the average root length before $(0 \mathrm{~h})$ treatment $\left(\mathrm{RL}_{0}\right)$. In Equation $(2)$, RRG is the ratio of RG under Al treatment and control.

\subsection{Sample Collection}

The root tips were quickly washed with distilled water, and then cut $1 \mathrm{~cm}$ from root apex from 6 seedlings (pooled together as one sample) and immediately frozen in liquid nitrogen. The samples were stored at $-80^{\circ} \mathrm{C}$ before use.

\subsection{RNA Isolation and RNA-seq Library Preparation}

Total RNA was extracted with TRIzol reagent (Invitrogen, Walthman, Massachusetts, USA) from $1 \mathrm{~g}$ of frozen root tips. After DNase I treatment, the quantity and quality of total RNA was assessed by measuring the $\mathrm{A}_{260 / 280}$ ratio and electrophoresis on a $1 \%$ formaldehyde-agarose gel. The mRNA was isolated by oligo (dT)-attached magnetic beads and subsequently fragmented using divalent cations under elevated temperature. Sixteen libraries were constructed as described previously [73] using NEB Next Ultra Directional RNA Library Prep Kit for Illumina. All libraries were sequenced by Illumina HiSeq 2500 at Berry Genomics Institute, Beijing, China. The RNA-seq data were submitted to NCBI database with the SRA accession number PRJNA591095.

\subsection{RNA-seq Analysis}

The FastQC (http://www.bioinformatics.babraham.ac.uk/projects/fastqc/) software package [74] was used for the quality control of raw data, and then SolexaQA_v.2.5 [75] was used to filter the poor-quality bases and trim the reads of which length was shorter than the cut-off value of 25 . We discarded the reads containing exceeded $\mathrm{N}$ and low-quality bases to get the clean reads for further analysis. The clean reads were then aligned to the soybean reference genome (Wm82a2.v1) using TopHat version 2.0.13 [76]. Then Cufflinks v2.1.1 [77] and Cuffmerge [78] were used to assemble the transcriptomes and quantify the gene expression level (fragments per kilobase per million, FPKM). Next, Cuffdiff [79] was used to find differentially expressed genes (DEGs) for different comparisons. In this study, DEGs were identified with the thresholds of $F D R<0.05$ and $\mid \log _{2}$ (fold change) $\mid>1$. The heat map with clustering analysis was constructed using $\log _{2}(\mathrm{FPKM}+1)$ by Mev4.9 software.

\subsection{Gene Annotation, Classification and Enrichment Analysis}

Genes were annotated based on the soybean genome annotation in SoyBase (https://www.soybase.org). All DEGs were compared to Kyoto Encyclopedia of Genes and Genomes (KEGG) for functional classifications [80]. Transcription factors were aligned to the Plant transcription factors Database 3.0 [81] and Protein family (Pfam) database [82] using the hmmscan v3.0 software [83]. Fisher's exact test $(p<0.01)$ and Benjamini-Kochberg procedure $(F D R<0.05)$ were performed to detect statistical enrichment of transcription factors (TFs) and KEGG pathways, in comparison with the soybean genome as the background. Gene Ontology (GO) enrichment analyses were performed using Singular Enrichment Analysis (SEA) method with $p<0.01$ and FDR $<0.05$ by agriGO [84].

\subsection{Gene Co-Expression Network Analysis}

The FPKM values of the genes in M-up-selected list were used for gene co-expression network analysis by WGCNA (version 1.49) [85]. The co-expressed gene sets (modules) were detected using the hierarchical clustering method. TOM and DynamicTreeCut functions were used for network 
construction and consensus module detection. After exploring the soft thresholds, we finally set the power to 7 , and minimum module size as 30 . The correlation between genes as well as the correlation between RRG and each module was measured by Pearson's correlation. The expression patterns of the modules were analyzed by STEM [86], and the visual co-expression network was constructed using Cytoscape (Version 3.6.1, The Cytoscape Consoritum, USA) [87].

\subsection{Quantitative Real-Time PCR}

A total of 12 candidate genes were selected to validate the RNA-seq data by quantitative real time PCR (qRT-PCR). We used $1000 \mathrm{ng}$ of total RNA for synthesizing the first-strand cDNAs. The qRT-PCRs were performed with LightCycler 480 instrument (Roche, Penzberg, Upper Bavaria, Germany), in a final volume of $20 \mu \mathrm{L}$ reaction solution containing $2 \mu \mathrm{L}$ of cDNA, $10 \mu \mathrm{L}$ of $2 X$ SYBR Green qPCR Mix (Takara, Japan) and $200 \mathrm{nM}$ of the forward and reverse primers (Table S12). The thermal cycling conditions were set as follows: 40 cycles of $95^{\circ} \mathrm{C}$ denaturation for $5 \mathrm{~s}, 58^{\circ} \mathrm{C}$ for $30 \mathrm{~s}$, and $72{ }^{\circ} \mathrm{C}$ for $45 \mathrm{~s}$. The reference gene GmEF-1 $\alpha$ was used as the internal control [33].

\subsection{Indaziflam Treatment}

After germination, three-day-old seedlings were transferred to $500 \mathrm{~mL}$ plastic beakers filled with $0.5 \mathrm{mM} \mathrm{CaCl}_{2}$ solution ( $\mathrm{pH} \mathrm{4.3)}$ for $24 \mathrm{~h}$. Then these seedlings were transferred to $0.5 \mathrm{mM} \mathrm{CaCl} 2$ solution ( $\mathrm{pH}$ 4.3) solutions containing 0 or $25 \mu \mathrm{M} \mathrm{AlCl}_{3}$ with different concentrations of indaziflam $(0,0.06,0.08$ and $0.10 \mathrm{nM}$, respectively). The root length was measured and RRG was calculated as described above, except that the RRG is the ratio of RG under indaziflam $(0.06,0.08$ and $0.10 \mathrm{nM})$ treatment and control (0 $\mathrm{nM}$ indaziflam).

\subsection{Statistical Analysis}

The RNA-seq analysis was described as above, and Student's $t$-tests were performed using Excel.

\section{Conclusions}

Two soybean varieties, $\mathrm{M}$ and $\mathrm{P}$, showed significant differences in $\mathrm{Al}$ tolerance (RRG) in this study. A total of 1799 genes showed up-regulation by Al stress specific to the Al-tolerant variety M but not the Al-sensitive variety $\mathrm{P}$, and 1050 genes were induced by $\mathrm{Al}$ in both varieties but with more fold change in $\mathrm{M}$ than P. There were 354 out of these 2849 genes that also showed higher expression levels in M than $\mathrm{P}$ under $\mathrm{Al}$ stress, which were enriched in the GO terms of cellular glucan metabolic process and regulation of transcription. There are five genes encoding cellulose synthases in the enriched GO term of cellular glucan metabolic process, and the treatment of soybean roots with the cellulose biosynthesis inhibitor resulted in decreased $\mathrm{Al}$ tolerance. These results suggest that cellulose production may play an important role in soybean tolerance to $\mathrm{Al}$ toxicity. This study also provides a list of candidate genes for further investigation on $\mathrm{Al}$ tolerance mechanisms and molecular breeding in soybean.

Supplementary Materials: The following are available online at http://www.mdpi.com/1422-0067/21/12/4316/s1, Figure S1: Sequencing saturation curves (A) and gene coverage analysis (B) of the 16 RNA-Seq samples; Figure S2: Gene ontology (GO) enrichment analysis of DEGs in M-up-selected; Figure S3: Gene ontology (GO) enrichment analysis of DEGs in M-down-selected; Figure S4: Gene ontology (GO) enrichment analysis of DEGs in M-up-high; Figure S5: Correlation between gene co-expression network modules and RRG; Table S1: Summary of the RNA-seq data in this study; Table S2: Detailed information of the RNA-seq data in this study; Table S3: Differentially Expressed Genes between Al and control (CK) in two soybean varieties of M90-24 (M) and Pella (P), respectively; Table S4: Significantly enriched KEGG Pathways in up- or down-regulated genes in M or P in response to $25 \mu \mathrm{M}$ $\mathrm{AlCl} 3(\mathrm{pH}=4.3)$ stress; Table S5: Differentially Expressed Genes between two soybean varieties of M90-24 (M) and Pella (P) under Al or control (CK) condition; Table S6: M-up-selected genes including the Al-responsive genes that showed specific to $\mathrm{M}$ or more up-regulation in $\mathrm{M}$ than P; Table S7: M-down-selected genes including the Al-responsive genes that showed specific to $\mathrm{M}$ or with more down-regulation in $\mathrm{M}$ than P; Table S8: Differently expressed genes in M-up-high list; Table S9: Differently expressed genes in M-down-low list; Table S10: Genes in the GO (0006073) term of cellular glucan metabolic process in M-up-high list; Table S11: Genes in the GO (0050794) term of regulation of cellular process in M-up-high list; Table S12: Primer pairs for qRT-PCR. 
Author Contributions: Y.L. conceived and designed the experiments. L.Z., J.C., Y.C. and J.L. performed the experiments. L.Z., S.Y., W.W. and Y.L. analyzed the data. L.Z., Y.L. and Z.H. contributed and interpretation of the results. J.G. and Y.L. contributed reagents/materials. L.Z. and Y.L. wrote and revised the manuscript. All authors have read and agreed to the published version of the manuscript.

Funding: This work was supported by the National Key R\&D Program for Crop Breeding (2016YFD0100304), the Fundamental Research Funds for the Central Universities (KYT201801), the National Natural Science Foundation of China (31371645), and the Program for Changjiang Scholars and Innovative Research Team in University (IRT_17R55).

Acknowledgments: The authors would like to thank Yufeng Wu, Nanjing Agricultural University, for his assistance in using the computational clouds.

Conflicts of Interest: The authors declare no conflict of interest.

\section{Abbreviations}

$\begin{array}{ll}\text { ABA } & \text { abscisic acid } \\ \text { ALMT } & \text { aluminum-activated malate transporter } \\ \text { CBI } & \text { cellulose biosynthesis inhibitor } \\ \text { DEG } & \text { differently expressed gene } \\ \text { FDR } & \text { false discovery rate } \\ \text { FPKM } & \text { fragments per kilobase per million } \\ \text { GO } & \text { Gene Ontology } \\ \text { KEGG } & \text { Kyoto Encyclopedia of Genes and Genomes } \\ \text { MATE } & \text { multidrug and toxin extrusion } \\ \text { RG } & \text { root growth } \\ \text { RRG } & \text { relative root growth } \\ \text { RNA-Seq } & \text { RNA sequencing } \\ \text { SA } & \text { salicylic acid } \\ \text { SEA } & \text { singular enrichment analysis } \\ \text { TF } & \text { transcription factor } \\ \text { XET } & \text { xyloglucan endo-transglycosylase }\end{array}$

\section{References}

1. Uexküll, H.R.V.; Mutert, E. Global extent, development and economic impact of acid soils. Plant Soil 1995, 171, 1-15. [CrossRef]

2. Kochian, L.V.; Pineros, M.A.; Liu, J.; Magalhaes, J.V. Plant adaptation to acid soils: The molecular basis for crop aluminum resistance. Annu. Rev. Plant Biol. 2015, 66, 571-598. [CrossRef] [PubMed]

3. Huang, B.Q.; Bai, J.H.; Xue, X.Q. Advances in studies on aluminum toxicity and tolerance in plants. Chin. Bull. Bot. 2001, 18, 385-395.

4. Bojórquez-Quintal, E.; Escalante-Magaña, C.; Echevarría-Machado, I.; Martínez-Estévez, M. Aluminum, a friend or foe of higher plants in acid soils. Front. Plant. Sci. 2017, 8, 1767. [CrossRef] [PubMed]

5. Ryan, P.R.; Tyerman, S.D.; Sasaki, T.; Furuichi, T.; Yamamoto, Y.; Zhang, W.H. The identification of aluminium-resistance genes provides opportunities for enhancing crop production on acid soils. J. Exp. Bot. 2011, 62, 9-20. [CrossRef]

6. Claudio, I.; Braulio, S.; Pilar, U.; Felipe, A.; Marjorie, R. Resistance mechanisms of Aluminum $\left(\mathrm{Al}^{3+}\right)$ phytotoxicity in cereals: Physiological, genetic and molecular basis. J. Soil Sci. Plant Nutr. 2008, 8, 57-71.

7. Ligaba-Osena, A.; Fei, Z.; Liu, J.; Xu, Y.; Shaff, J.; Lee, S.C. Loss-of-function mutation of the calcium sensor CBL1 increases aluminum sensitivity in Arabidopsis. New Phytol. 2017, 214, 830-841. [CrossRef]

8. Ikka, T.; Kobayashi, Y.; Iuchi, S.; Sakurai, N.; Shibata, D.; Kobayashi, M.; Koyama, H. Natural variation of Arabidopsis thaliana reveals that aluminum resistance and proton resistance are controlled by different genetic factors. Theor. Appl. Genet. 2007, 115, 709-719. [CrossRef]

9. Marschner, H. Mechanisms of adaptation of plants to acid soil. Plant Soil 1991, 134, 1-20. [CrossRef]

10. Kochian, L.V.; Hoekenga, O.A.; Pineros, M.A. How do crop plants tolerate acid soils? Mechanisms of aluminum tolerance and phosphorous efficiency. Annu. Rev. Plant Biol. 2004, 55, 459-493. [CrossRef] 
11. Kochian, L.V. Cellular mechanisms of aluminum toxicity and resistance in plants. Annu. Rev. Plant Biol. Mol. Biol. 1995, 46, 237-260. [CrossRef]

12. Ma, J.F.; Chen, Z.C.; Shen, R.F. Molecular mechanisms of Al tolerance in gramineous plants. Plant Soil 2014, 381, 1-12. [CrossRef]

13. Ma, J.F.; Yamamoto, R.; Nevins, D.J.; Matsumoto, H.; Brown, P.H. Al binding in the epidermis cell wall inhibits cell elongation of okra hypocotyl. Plant Cell Physiol. 1999, 40, 549-556. [CrossRef]

14. Wang, Y.; Stass, A.; Horst, W.J. Apoplastic binding of aluminum is involved in silicon-induced amelioration of aluminum toxicity in maize. Plant Physiol. 2004, 136, 3762-3770. [CrossRef]

15. Chang, Y.C.; Yamamoto, Y.; Matsumoto, H. Accumulation of aluminium in the cell wall pectin in cultured tobacco (Nicotiana tabacum L.) cells treated with a combination of aluminium and iron. Plant Cell Environ. 1999, 22, 1009-1017. [CrossRef]

16. Yang, J.L.; Li, Y.Y.; Zhang, Y.J.; Zhang, S.S.; Wu, Y.R.; Wu, P.; Zheng, S.J. Cell wall polysaccharides are specifically involved in the exclusion of aluminum from the rice root apex. Plant Physiol. 2008, 146, 602-611. [CrossRef]

17. Yang, J.L.; Zhu, X.F.; Peng, Y.X.; Zheng, C.; Li, G.X.; Liu, Y.; Shi, Y.Z.; Zheng, S.J. Cell wall hemicellulose contributes significantly to aluminum adsorption and root growth in Arabidopsis. Plant Physiol. 2011, 155, 1885-1892. [CrossRef]

18. Van, H.L.; Kuraishi, S.; Sakurai, N. Aluminum-induced rapid root inhibition and changes in cell-wall components of squash seedlings. Plant Physiol. 1994, 106, 971-976. [CrossRef]

19. Ellis, C.; Karafyllidis, I.; Wasternack, C.; Turner, J.G. The Arabidopsis mutant cev1 links cell wall signaling to jasmonate and ethylene responses. Plant Cell. 2002, 14, 1557-1566. [CrossRef]

20. Cano-Delgado, A.; Penfield, S.; Smith, C.; Catley, M.; Bevan, M. Reduced cellulose synthesis invokes lignification and defense responses in Arabidopsis thaliana. Plant Mol. Biol. 2003, 34, 351-362. [CrossRef]

21. Horst, W.J.; Wang, Y.; Eticha, D. The role of the root apoplast in aluminium-induced inhibition of root elongation and in aluminium resistance of plants: A review. Ann. Bot. 2010, 106, 185-197. [CrossRef] [PubMed]

22. Ma, J.F.; Hiradate, S.; Matsumoto, H. High aluminum resistance in buckwheat II. Oxalic acid detoxifies aluminum internally. Plant Physiol. 1998, 117, 753-759. [CrossRef] [PubMed]

23. Ma, J.F.; Hiradate, S. Form of aluminium for uptake and translocation in buckwheat (Fagopyrum esculentum, Moench). Planta 2000, 211, 355-360. [CrossRef] [PubMed]

24. Shen, R.; Ma, J.F.; Kyo, M.; Iwashita, T. Compartmentation of aluminium in leaves of an Al-accumulator, Fagopyrum esculentum Moench. Planta 2002, 215, 394-398. [CrossRef] [PubMed]

25. Shen, R.; Iwashita, T.; Ma, J.F. Form of $\mathrm{Al}$ changes with $\mathrm{Al}$ concentration in leaves of buckwheat. J. Exp. Bot. 2004, 55, 131-136. [CrossRef]

26. Lei, G.J.; Yokosho, K.; Yamaji, N.; Fujiikashino, M.; Ma, J.F. Functional characterization of two half-size ABC transporter genes in aluminium-accumulating buckwheat. New Phytol. 2017, 215, 1080-1089. [CrossRef]

27. Ma, J.F.; Ryan, P.R.; Delhaize, E. Aluminium tolerance in plants and the complexing role of organic acids. Trends Plant Sci. 2001, 6, 273-278. [CrossRef]

28. Maron, L.G.; Piñeros, M.A.; Guimarães, C.T.; Magalhaes, J.V.; Pleiman, J.K.; Mao, C.Z. Two functionally distinct members of the MATE (multi-drug and toxic compound extrusion) family of transporters potentially underlie two major aluminum tolerance QTLs in maize. Plant Mol. Biol. 2010, 61, 728-740. [CrossRef]

29. Yokosho, K.; Yamaji, N.; Jian, F.M. Isolation and characterisation of two MATE genes in rye. Funct. Plant Biol. 2010, 37, 296-303. [CrossRef]

30. Sasaki, T.; Yamamoto, Y.; Ezaki, B.; Katsuhara, M.; Ahn, S.J.; Ryan, P.R.; Delhaize, E.; Matsumoto, H. A wheat gene encoding an aluminum-activated malate transporter. Plant J. 2004, 37, 645-653. [CrossRef]

31. Ligaba, A.; Matsumoto, H. The BnALMT1 and BnALMT2 genes from rape encode aluminum-activated malate transporters that enhance the aluminum resistance of plant cells. Plant Physiol. 2006, 142, 1294-1303. [CrossRef] [PubMed]

32. Wu, D.; Man, Z.; Shen, S.; Fu, Y.; Sasaki, T.; Yamamoto, Y. Al-induced secretion of organic acid, gene expression and root elongation in soybean roots. Acta Physiol. Plant. 2013, 35, 223-232. [CrossRef]

33. Liang, C.; Pineros, M.A.; Tian, J.; Yao, Z.; Sun, L.; Liu, J.; Shaff, J.; Coluccio, A.; Kochian, L.V.; Liao, H. Low pH, aluminum, and phosphorus coordinately regulate malate exudation through GmALMT1 to improve soybean adaptation to acid soils. Plant Physiol. 2013, 161, 1347-1361. [CrossRef] [PubMed] 
34. Ligaba, A.; Dreyer, I.; Margaryan, A.; Schneider, D.J.; Kochian, L.; Pineros, M. Functional, structural and phylogenetic analysis of domains underlying the Al sensitivity of the aluminum-activated malate/anion transporter, TaALMT1. Plant J. 2013, 76, 766-780. [CrossRef]

35. Magalhaes, J.V.; Liu, J.; Guimarães, C.T.; Lana, U.G.; Alves, V.M.; Wang, Y.H. A gene in the multidrug and toxic compound extrusion (MATE) family confers aluminum tolerance in sorghum. Nat. Genet. 2007, 39, 1156-1161. [CrossRef]

36. Liu, J.P.; Magalhaes, J.V.; Shaff, J.; Kochian, L.V. Aluminum-activated citrate and malate transporters from the MATE and ALMT families function independently to confer Arabidopsis aluminum tolerance. Plant J. 2009, 57, 389-399. [CrossRef]

37. Yokosho, K.; Yamaji, N.; Ma, J.F. An Al-inducible MATE gene is involved in external detoxification of Al in rice. Plant Mol. Biol. 2011, 68, 1061-1069. [CrossRef]

38. Liu, K.S. Soybeans: Chemistry, Technology and Utilization; Springer: Berlin, Germany, 1997.

39. Ying, X.F.; Liu, P.; Xu, G.; Lu, Q.; Zhu, S. Screening of soybean genotypes with tolerance to aluminum toxicity and study of the screening indices. Chin. J. Oil Crop Sci. 2005, 27, 46-51.

40. Bianchihall, C.M.; Carter, T.E.; Bailey, M.A.; Mian, M.a.R.; Rufty, T.W.; Ashley, D.A.; Boerma, H.R.; Arellano, C.; Hussey, R.S.; Parrott, W.A. Aluminum tolerance associated with quantitative trait loci derived from soybean PI 416937 in hydroponics. Crop Sci. 2000, 40, 538-545. [CrossRef]

41. Nian, H.; Yang, Z.; Huang, H.; Yan, X.; Matsumoto, H. Citrate secretion induced by aluminum stress may not be a key mechanism responsible for differential aluminum tolerance of some soybean genotypes. J. Plant Nutr. 2007, 27, 2047-2066. [CrossRef]

42. Korir, P.C.; Zhang, J.; Wu, K. Association mapping combined with linkage analysis for aluminum tolerance among soybean cultivars released in Yellow and Changjiang River Valleys in China. Theor. Appl. Genet. 2013, 126, 1659-1675. [CrossRef] [PubMed]

43. Huang, S.; Shahla, S.; Baloch, K. Identification and analysis of differentially expressed genes associated with aluminum response in two soybean cultivars by cDNA-RAPD. Pak. J. Bot. 2015, 47, 711-715.

44. You, J.; Zhang, H.; Liu, N.; Gao, L.; Kong, L.; Yang, Z. Transcriptomic responses to aluminum stress in soybean roots. Genome 2011, 54, 923-933. [CrossRef] [PubMed]

45. Chen, W.W.; Xu, J.M.; Jin, J.F.; Lou, H.Q.; Fan, W.; Yang, J.L. Genome-wide transcriptome analysis reveals conserved and distinct molecular mechanisms of al resistance in buckwheat (fagopyrum esculentum moench) leaves. Int. J. Mol. Sci. 2017, 18, 1859. [CrossRef]

46. Tsutsui, T.; Yamaji, N.; Huang, C.F.; Motoyama, R.; Nagamura, Y.; Ma, J.F. Comparative genome-wide transcriptional analysis of Al-responsive genes reveals novel $\mathrm{Al}$ tolerance mechanisms in rice. PLoS ONE 2012, 7, e48197. [CrossRef]

47. Yamaji, N.; Huang, C.F.; Nagao, S. A zinc finger transcription factor ART1 regulates multiple genes implicated in aluminum tolerance in rice. Plant Cell 2009, 21, 3339-3349. [CrossRef]

48. Yang, Z.B.; Eticha, D.; Rotter, B. Physiological and molecular analysis of polyethylene glycol-induced reduction of aluminium accumulation in the root tips of common bean. J. Exp. Bot. 2012, 63, 3109-3125. [CrossRef]

49. Li, H.; Wang, B.; Zhang, Q.; Wang, J.; King, G.B. Genome-wide analysis of the auxin / indoleacetic acid, (Aux/IAA) gene family in allotetraploid rapeseed (Brassica napus, L.). BMC Plant Biol. 2017, 17, 204. [CrossRef]

50. Shani, E.; Salehin, M.; Zhang, Y. Plant stress tolerance requires auxin-sensitive aux/iaa transcriptional repressors. Curr. Biol. 2017, 27, 437-444. [CrossRef]

51. Brabham, C.; Lei, L.; Gu, Y.; Stork, J.; Barrett, M.; Debolt, S. Indaziflam herbicidal action: A potent cellulose biosynthesis inhibitor. Plant Physiol. 2014, 166, 1177-1185. [CrossRef]

52. Singh, S.; Tripathi, D.K.; Singh, S.; Sharma, S.; Dubey, N.K.; Chauhan, D.K. Toxicity of aluminium on various levels of plant cells and organism: A review. Environ. Exp. Bot. 2007, 137, 177-193. [CrossRef]

53. Teraoka, T.; Kaneko, M.S.; Yoshimura, E. Aluminum rapidly inhibits cellulose synthesis in roots of barley and wheat seedlings. J. Plant Physiol. 2002, 159, 17-23. [CrossRef]

54. Burn, J.E.; Hurley, U.A.; Birch, R.J.; Arioli, T.; Cork, A.; Williamson, R.E. The cellulose-deficient Arabidopsis mutant $r s w 3$ is defective in a gene encoding a putative glucosidase II, an enzyme processing N-glycans during ER quality control. Plant J. 2002, 32, 949-960. [CrossRef] [PubMed]

55. Ambroise, V.; Legay, S.; Guerriero, G.; Hausman, J.F.; Cuypers, A.; Sergeant, K. The roots of plant frost hardiness and tolerance. Plant Cell Physiol. 2020, 61, 3-20. [CrossRef] [PubMed] 
56. Arisha, M.H.; Aboelnasr, H.; Ahmad, M.Q.; Liu, Y.; Tang, W.; Gao, R.; Yan, H.; Kou, M.; Wang, X.; Zhang, Y.; et al. Transcriptome sequencing and whole genome expression profiling of hexaploid sweetpotato under salt stress. BMC Genom. 2020, 21, 197. [CrossRef]

57. Wang, T.; McFarlane, H.E.; Persson, S. The impact of abiotic factors on cellulose synthesis. J. Exp. Bot. 2016, 67, 543-552. [CrossRef] [PubMed]

58. Zhu, X.F.; Shi, Y.Z.; Lei, G.J.; Fry, S.C.; Zhang, B.C.; Zhou, Y.H. XTH31, encoding an in vitro xeh/xet-active enzyme, regulates aluminum sensitivity by modulating in vivo xet action, cell wall xyloglucan content, and aluminum binding capacity in Arabidopsis. Plant Cell 2012, 24, 4731-4747. [CrossRef]

59. Finkelstein, R.R.; Wang, M.L.; Lynch, T.J.; Rao, S.; Goodman, H.M. The Arabidopsis Abscisic Acid Response Locus ABI4 Encodes an APETALA2 Domain Protein. Plant Cell 1998, 10, 1043-1054. [CrossRef]

60. Pandey, P.; Srivastava, R.K.; Dubey, R.S. Salicylic acid alleviates aluminum toxicity in rice seedlings better than magnesium and calcium by reducing aluminum uptake, suppressing oxidative damage and increasing antioxidative defense. Ecotoxicology 2013, 22, 656-670. [CrossRef]

61. Zhang, G.; Chen, M.; Chen, X.; Xu, Z.; Guan, S.; Li, L.C.; Li, A.; Guo, J.; Mao, L.; Ma, Y. Phylogeny, gene structures, and expression patterns of the ERF gene family in soybean (Glycine max L.). J. Exp. Bot. 2008, 59, 4095-4107. [CrossRef]

62. Jisha, V.; Dampanaboina, L.; Vadasser, J.; Mithöfer, A.; Kappara, S.; Ramanan, R. Overexpression of an AP2/ERF Type transcription factor oserebp1 confers biotic and abiotic stress tolerance in rice. PLoS ONE 2015, 10, e0127831. [CrossRef]

63. Reyna-Llorens, I.; Corrales, I.; Poschenrieder, C.; Barcelo, J.; Cruz-Ortega, R. Both aluminum and ABA induce the expression of an ABC-like transporter gene (FeALS3) in the Al-tolerant species Fagopyrum esculentum. Environ. Exp. Bot. 2015, 111, 74-82. [CrossRef]

64. Wang, P.; Yu, W.; Zhang, J.; Rengel, Z.; Xu, J.; Han, Q.; Chen, L.; Li, K.; Yu, Y.; Chen, Q. Auxin enhances aluminium-induced citrate exudation through upregulation of GmMATE and activation of the plasma membrane H+-ATPase in soybean roots. Ann. Bot. 2016, 118, 933-940. [CrossRef] [PubMed]

65. Mattiello, L.; Kirst, M.; Silva, F.R.D.; Jorge, R.A.; Menossi, M. Transcriptional profile of maize roots under acid soil growth. BMC Plant Biol. 2010, 10, 196. [CrossRef]

66. Goodwin, S.B.; Sutter, T.R. Microarray analysis of Arabidopsis genome response to aluminum stress. Biol. Plant. 2009, 53, 85-99. [CrossRef]

67. Yang, Y.; Wang, Q.L.; Geng, M.J.; Guo, Z.H.; Zhao, Z.Q. Effect of indole-3-acetic acid on aluminum-induced efflux of malic acid from wheat (Triticum aestivum L). Plant Soil 2011, 346, 215-230. [CrossRef]

68. Huang, C.F.; Yamaji, N.; Mitani, N.; Yano, M.; Nagamura, Y.; Ma, J.F. A bacterial-type ABC transporter is involved in aluminum tolerance in rice. Plant Cell 2009, 21, 655-667. [CrossRef]

69. Houde, M.; Diallo, A.O. Identification of genes and pathways associated with aluminum stress and tolerance using transcriptome profiling of wheat near-isogenic lines. BMC Genom. 2008, 9, 400. [CrossRef]

70. Liu, J.; Li, Y.; Wang, W.; Gai, J.; Li, Y. Genome-wide analysis of MATE transporters and expression patterns of a subgroup of MATE genes in response to aluminum toxicity in soybean. BMC Genom. 2016, 17, 223. [CrossRef]

71. Wu, W.; Lin, Y.; Chen, Q. Functional conservation and divergence of soybean GmStop1 members in proton and aluminum tolerance. Front Plant Sci. 2018, 9, 570-594. [CrossRef]

72. Famoso, A.N.; Zhao, K.; Clark, R.T.; Tung, C.W.; Wright, M.H.; Bustamante, C. Genetic architecture of aluminum tolerance in rice (Oryza sativa) determined through genome-wide association analysis and QTL mapping. PLoS Genet. 2011, 7, e1002221. [CrossRef] [PubMed]

73. Grabherr, M.G.; Haas, B.J.; Yassour, M.; Levin, J.Z.; Thompson, D.A.; Amit, I.; Adiconis, X.; Fan, L.; Raychowdhury, R.; Zeng, Q. Full-length transcriptome assembly from RNA-Seq data without a reference genome. Nat. Biotechnol. 2011, 29, 644-652. [CrossRef] [PubMed]

74. Cock, P.J.; Fields, C.J.; Goto, N.; Heuer, M.L.; Rice, P.M. The Sanger FASTQ file format for sequences with quality scores, and the Solexa/Illumina FASTQ variants. Nucleic Acids Res. 2010, 38, 1767-1771. [CrossRef]

75. Cox, M.P.; Peterson, D.A.; Biggs, P.J. SolexaQA: At-a-glance quality assessment of Illumina second-generation sequencing data. BMC Bioinform. 2010, 11, 485. [CrossRef]

76. Trapnell, C.; Pachter, L.; Salzberg, S.L. TopHat: Discovering splice junctions with RNA-Seq. Bioinformatics 2009, 25, 1105-1111. [CrossRef] [PubMed] 
77. Trapnell, C.; Roberts, A.; Goff, L.; Pertea, G.; Kim, D.; Kelley, D.R.; Pimentel, H.; Salzberg, S.L.; Rinn, J.L.; Pachter, L. Differential gene and transcript expression analysis of RNA-seq experiments with TopHat and Cufflinks. Nat. Protoc. 2012, 7, 562-578. [CrossRef]

78. Ghosh, S.; Chan, C.K. Analysis of RNA-Seq data using tophat and cufflinks. Methods Mol. Biol. 2016, 1374, 339-361.

79. Trapnell, C.; Hendrickson, D.G.; Sauvageau, M.; Goff, L.; Rinn, J.L.; Pachter, L. Differential analysis of gene regulation at transcript resolution with RNA-seq. Nat Biotechnol. 2013, 31, 46-53. [CrossRef] [PubMed]

80. Kanehisa, M.; Goto, S.; Kawashima, S.; Okuno, Y.; Hattori, A.M. The KEGG resource for deciphering the genome. Nucleic Acids Res. 2004, 32, D277-D280. [CrossRef]

81. Jin, J.; Zhang, H.; Kong, L.; Gao, G.; Luo, J. PlantTFDB 3.0: A portal for the functional and evolutionary study of plant transcription factors. Nucleic Acids Res. 2014, 42, 1182-1187. [CrossRef]

82. Finn, R.D.; Bateman, A.; Clements, J.; Coggill, P.; Eberhardt, R.Y.; Eddy, S.R. Pfam: The protein families database. Nucleic Acids Res. 2014, 42, 222-230. [CrossRef] [PubMed]

83. Johnson, L.S.; Eddy, S.R.; Portugaly, E. Hidden Markov model speed heuristic and iterative HMM search procedure. BMC Bioinform. 2010, 11, 431. [CrossRef] [PubMed]

84. Du, Z.; Zhou, X.; Ling, Y.; Zhang, Z.; Su, Z. agriGO: A GO analysis toolkit for the agricultural community. Nucleic Acids Res. 2010, 38, W64-W70. [CrossRef] [PubMed]

85. Langfelder, P.; Horvath, S. WGCNA: An R package for weighted correlation network analysis. BMC Bioinform. 2008, 9, 559. [CrossRef]

86. Ernst, J.; Bar-Joseph, Z. STEM: A tool for the analysis of short time series gene expression data. BMC Bioinform. 2006, 7, 191. [CrossRef]

87. Shannon, P.; Markiel, A.; Ozier, O.; Baliga, N.S.; Wang, J.T.; Ramage, D.; Amin, N.; Schwikowski, B.; Ideker, T. Cytoscape: A software environment for integrated models of biomolecular interaction networks. Genome Res. 2003, 13, 2498-2504. [CrossRef]

(C) 2020 by the authors. Licensee MDPI, Basel, Switzerland. This article is an open access article distributed under the terms and conditions of the Creative Commons Attribution (CC BY) license (http://creativecommons.org/licenses/by/4.0/). 